\title{
Further evaluation of differential expression of keratoconus candidate genes in human corneas
}

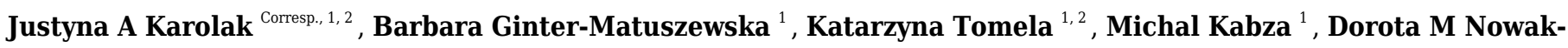 \\ Malczewska $^{1}$, Malgorzata Rydzanicz ${ }^{3}$, Piotr Polakowski ${ }^{4}$, Jacek P Szaflik ${ }^{4}$, Marzena Gajecka ${ }^{1,2}$ \\ ${ }^{1}$ Chair and Department of Genetics and Pharmaceutical Microbiology, Poznan University of Medical Sciences, Poznan, Poland \\ 2 Institute of Human Genetics, Polish Academy of Sciences, Poznan, Poland \\ 3 Department of Medical Genetics, Medical University of Warsaw, Warsaw, Poland \\ 4 Department of Ophthalmology, Medical University of Warsaw, Warsaw, Poland \\ Corresponding Author: Justyna A Karolak \\ Email address: jkarolak@ump.edu.pl
}

Background: Keratoconus (KTCN) is a progressive eye disease, characterized by changes in the shape and thickness of the cornea that results in loss of visual acuity. While numerous KTCN candidate genes have been identified, the genetic etiology of the disease remains undetermined. To further investigate and verify the contribution of particular genetic factors to KTCN, we assessed 45 candidate genes previously indicated as involved in KTCN etiology based on transcriptomic and genomic data. Methods: The RealTime ready Custom Panel, covering $45 \mathrm{KTCN}$ candidate genes and two reference transcripts, has been designed. Then, the expression profiles have been assessed using the RT-qPCR assay in six KTCN and six non-KTCN human corneas, obtained from individuals undergoing a penetrating keratoplasty procedure. Results: In total, 35 genes exhibiting differential expression between KTCN and non-KTCN corneas have been identified. Among these genes were ones linked to the extracellular matrix formation, including collagen synthesis or the TGF- $\beta$, Hippo, and Wnt signaling pathways. The most downregulated transcripts in KTCN corneas were CTGF, TGFB3, ZNF469, COL5A2, SMAD7, and SPARC, while TGFBI and $S L C 4 A 11$ were the most upregulated ones. Hierarchical clustering of expression profiles demonstrated almost clear separation between KTCN and non-KTCN corneas. The gene expression levels determined using RT-qPCR showed a strong correlation with previous RNA sequencing (RNA-Seq) results. Conclusions: A strong correlation between RT-qPCR and earlier RNA-Seq data confirms the possible involvement of genes from collagen synthesis and the TGF- $\beta$, Hippo, and Wnt signaling pathways in KTCN etiology. Our data also revealed altered expression of several genes, such as LOX, SPARC, and ZNF469, in which single nucleotide variants have been frequently identified in KTCN. These findings further highlight the heterogeneous nature of KTCN. 
1 Further evaluation of differential expression of keratoconus candidate genes in human 2 corneas

3 Justyna A. Karolak ${ }^{1,2}$, Barbara Ginter-Matuszewska ${ }^{1}$, Katarzyna Tomela ${ }^{1,2}$, Michal Kabza ${ }^{1}$, Dorota

4 M. Nowak-Malczewska ${ }^{1}$, Malgorzata Rydzanicz ${ }^{3}$, Piotr Polakowski ${ }^{4}$, Jacek P. Szaflik ${ }^{4}$, Marzena 5 Gajecka ${ }^{1,2}$

$7 \quad{ }^{1}$ Chair and Department of Genetics and Pharmaceutical Microbiology, Poznan University of

8 Medical Sciences, Poznan, Poland;

9 2Institute of Human Genetics, Polish Academy of Sciences, Poznan, Poland;

$10{ }^{3}$ Department of Medical Genetics, Medical University of Warsaw, Warsaw, Poland;

$11{ }^{4}$ Department of Ophthalmology, Medical University of Warsaw, Warsaw, Poland

Correspondence:

16 Justyna A. Karolak, Ph.D.

17 Poznan University of Medical Sciences

18 Chair and Department of Genetics and Pharmaceutical Microbiology

19 Swiecickiego 4, 60-781 Poznan, Poland

20 tel. +48618546726 , fax. +48618546720

21 jkarolak@ump.edu.pl 


\section{Abstract}

26

Background: Keratoconus (KTCN) is a progressive eye disease, characterized by changes in the shape and thickness of the cornea that results in loss of visual acuity. While numerous KTCN candidate genes have been identified, the genetic etiology of the disease remains undetermined. To further investigate and verify the contribution of particular genetic factors to KTCN, we assessed 45 candidate genes previously indicated as involved in KTCN etiology based on transcriptomic and genomic data.

Methods: The RealTime ready Custom Panel, covering $45 \mathrm{KTCN}$ candidate genes and two reference transcripts, has been designed. Then, the expression profiles have been assessed using the RT-qPCR assay in six KTCN and six non-KTCN human corneas, obtained from individuals undergoing a penetrating keratoplasty procedure.

Results: In total, 35 genes exhibiting differential expression between KTCN and non-KTCN corneas have been identified. Among these genes were ones linked to the extracellular matrix formation, including collagen synthesis or the TGF- $\beta$, Hippo, and Wnt signaling pathways. The most downregulated transcripts in KTCN corneas were CTGF, TGFB3, ZNF469, COL5A2, SMAD7, and SPARC, while TGFBI and SLC4A11 were the most upregulated ones. Hierarchical clustering of expression profiles demonstrated almost clear separation between KTCN and nonKTCN corneas. The gene expression levels determined using RT-qPCR showed a strong correlation with previous RNA sequencing (RNA-Seq) results.

Conclusions: A strong correlation between RT-qPCR and earlier RNA-Seq data confirms the possible involvement of genes from collagen synthesis and the TGF- $\beta$, Hippo, and Wnt signaling pathways in KTCN etiology. Our data also revealed altered expression of several genes, such as 
$47 L O X, S P A R C$, and ZNF469, in which single nucleotide variants have been frequently identified in

48 KTCN. These findings further highlight the heterogeneous nature of KTCN.

49

50

51

52

53

54

55

56

57

58

59

60

61

62

63

64

65

66

67

68

69

\section{Introduction}

Keratoconus (KTCN) is a progressive eye disorder characterized by thinning and conically shaped protrusion of the cornea, resulting in severe visual impairment (Rabinowitz, 1998). The first symptoms of KTCN usually appear during the second or third decade of life (Rabinowitz, 1998). However, individuals with early-onset KTCN have also been reported (Léoni-Mesplié et al., 2012). The estimated prevalence of KTCN varies between 1 in 375 and 1 in 2,000 individuals and depends on geographic location and ethnic origin (Godefrooij et al., 2016).

KTCN is considered a multifactorial disease with a substantial genetic contribution, supported by evidence from twin, family, and population studies (Tuft et al., 2012; Naderan et al., 2016; Lu et al., 2013). Because of the complex etiology and the genetic heterogeneity of the disease, the identification of specific risk factors for KTCN is difficult. However, the use of various approaches has already allowed detection of many candidate genes that could be implicated in KTCN as have been previously reviewed (Nowak \& Gajecka, 2011; Abu-Amero, Al-Muammar \& Kondkar, 2014; Bykhovskaya, Margines \& Rabinowitz, 2016; Karolak \& Gajecka, 2017; Valgaeren, Koppen \& Van Camp, 2018; Loukovitis et al., 2018; Lucas \& Burdon, 2020).

More than 20 chromosomal regions linked to KTCN have been identified (Hameed et al., 2000; Fullerton et al., 2002; Tyynismaa et al., 2002; Hughes et al., 2003; Brancati et al., 2004; Hutchings et al., 2005; Tang et al., 2005; Li et al., 2006; Burdon et al., 2008; Bisceglia et al., 2009; Gajecka et al., 2009; Liskova et al., 2010; Rosenfeld et al., 2011; Nowak et al., 2013), including 
70 loci in 5q21.2 and 5q31.1-q35.3 which have been replicated independently in different populations

71 (Tang et al., 2005; Li et al., 2006; Bisceglia et al., 2009; Rosenfeld et al., 2011; Bykhovskaya et

al., 2016b). Linkage studies also have led to the identification of a few potential KTCN candidate genes, including $S P A R C, I L 1 R N$, and $S K P 1$. These genes encode a cysteine-rich acidic matrixassociated protein, IL1 receptor antagonist, and S-phase kinase-associated protein 1 that are known to be involved in the extracellular matrix (ECM) formation, immune response, and ubiquitination, respectively (Bisceglia et al., 2009; Nowak et al., 2013; Karolak et al., 2016a).

Genome-wide association studies (GWAS) have identified several loci that show significant or suggestive association with $\mathrm{KTCN}$, including the promoter and upstream region of the HGF (hepatocyte growth factor) gene, (Burdon et al., 2011; Sahebjada et al., 2014), as well as the LOX (lysyl oxidase) (Bykhovskaya et al., 2012; Hasanian-Langroudi et al., 2015), and ZNF469 (zinc finger protein 469) (Lu et al., 2013; Sahebjada et al., 2013) genes. Although the exact role of these genes in KTCN etiology is not fully established, some evidence suggested their involvement participate in ECM homeostasis in the human cornea (Burkitt Wright et al., 2011; Burdon et al., 2011; Dudakova et al., 2012).

A gene approach, utilizing a direct screening of functional candidate genes for KTCN, has allowed detection of numerous promising genes implicated in KTCN etiology. Among them were VSX1 (visual system homeobox 1) and SOD1 (superoxide dismutase isoenzyme 1) (Héon et al., 2002; Udar et al., 2006), involved in wound healing (Barbaro et al., 2006) and oxidative stress (Udar et al., 2006), respectively. Other candidates genes include TGFBI (transforming growth factor beta-induced) or ZEB1 (zinc-finger E-box binding homeobox 1), involved in corneal dystrophies (Guan et al., 2012; Lechner et al., 2013) or COL4A1, COL4A2, COL4A2, and COL4A1 
92 (Stabuc-Silih et al., 2009; Karolak et al., 2011), encoding collagen proteins responsible for the 93 proper function of the cornea.

94

95

96

97

98

Gene expression studies are also a valuable source of information about functional genes and pathways important for KTCN pathogenesis. A high-throughput RNA sequencing (RNA-Seq) showed a serious alteration of numerous genes in KTCN corneas (Kabza et al., 2017). The most significant downregulation was observed among genes responsible for proper corneal organization and regulation of corneal ECM remodeling that belong to the TGF- $\beta$, Hippo, and Wnt signaling and collagen synthesis and maturation networks (Kabza et al., 2017). Abnormalities within genes involved in ECM have also been reported in subsequent RNA- and DNA-based studies (Khaled et al., 2018; You et al., 2018; Sharif et al., 2019; Karolak et al., 2020). Thus, disruptions within these molecular cascades could be potentially responsible for corneal abnormalities underlying the development of KTCN.

While the genes mentioned above have been hypothesized to play a role in KTCN, some of these identified factors account for a limited number of individuals only, being found in single families or particular studied populations. Also, in some cases, the results of the initial findings are contradictory. Thus, in this study, we have taken advantage of the previous RNA- and DNAbased KTCN analyses to select 45 candidate genes for further investigation aiming to validate their contribution to KTCN. The possible involvement of these genes in disease etiology was reevaluated using the RealTime ready Custom Panels in the RT-qPCR experiments, performed in KTCN and non-KTCN corneas.

\section{Methods}

Subjects 

underwent a complete ophthalmic evaluation. The KTCN diagnosis was made based on the previously described criteria (Karolak et al., 2016b; Kabza et al., 2017). The clinical characteristics of all enrolled individuals are shown in Table S1. All individuals provided written informed consent for participation in the study, in accordance with the Declaration of Helsinki. The research protocol was approved by the Institutional Review Board at Poznan University of Medical Sciences (453/14 and 755/19).

\section{Material}

The corneas were obtained from previously evaluated Polish KTCN (KC15, KC16, KC17, KC18, KC19, KC20) and non-KTCN (KR19, KR21, KR23, KR24, KR25, KR49) individuals, undergoing penetrating keratoplasty procedure (Karolak et al., 2016b; Kabza et al., 2017). Six nonKTCN corneas, used as controls, were collected from patients who were referred for corneal transplantation for different reasons, including corneal ulcer (KR21), bullous keratopathy (KR23, KR25), and history of the ocular trauma (KR24, KR49) (Table S1). RNA samples from all corneal tissues have been already extracted with a Total RNA Purification Kit (Norgen Biotek, Thorold, ON, Canada) as described (Kabza et al., 2017). All but one (KR49) RNA samples used in this study have also been assessed in the prior comprehensive RNA-Seq experiment (Kabza et al., 2017).

Candidate gene assay design results and previous genomic data. The first KTCN candidate gene set included 26 genes that have 
137 genes and encode core elements of collagen synthesis and maturation pathways, the TGF- $\beta$, Hippo,

138 and Wnt signaling pathways, as well as their potential regulators (Kabza et al., 2017). The second

139 set consists of 19 genes that have been previously reported as involved in KTCN based on the

140 detection of putative variants within the gene, localization within the linkage region, or proximity

141 to variants associated with KTCN. The selected genes are involved in inflammation, intracellular

142 signaling, ubiquitination, and other processes reported as crucial for the functioning of the eye or

143 disease development. The complete list of studied genes is presented in Table S2.

144 RT-qPCR analysis

145 To analyze gene expression profiles, total RNA samples from six KTCN and six non-

146 KTCN corneal tissues were reverse transcribed to cDNA with the Transcriptor First Strand cDNA

147 Synthesis Kit (Roche Diagnostics, Penzberg, Germany), according to the manufacturer's 148 procedure. Expression levels of 45 candidate KTCN genes and two housekeeping transcripts 149 (Table S2) were assessed using the RealTime ready Custom Panel 96 (Roche), containing pre150 plated primer pairs and probes. RT-qPCR analyses were conducted using the LightCycler 96

151 System (Roche) in a total volume of $20 \mu 1$ containing the FastStart Essential DNA Probe Master 152 (Roche), and $0.5 \mathrm{ng}$ of cDNA. Each reaction was performed in triplicate.

153

154

155

156

157

158

159

\section{$R T-q P C R$ data analysis}

Relative quantification of the gene expression was normalized to the level of the GAPDH and IPO8 transcripts with the comparative $\mathrm{C}_{\mathrm{T}}$ method. The $\mathrm{R}$ environment was used to analyze differential expression and to generate a heat map showing hierarchical clustering (Ward linkage) of KTCN and non-KTCN samples based on the expression profiles (R Development Core Team, 2008). The statistical significance of differential gene expression was evaluated using Student's $t$ test. The adjusted p-values were calculated using the Benjamini-Hochberg (FDR) procedure. 
160

161

162

163

164

165

166

167

168

169

170

171

172

173

174

175

176

177

178

179

180

181

182

\section{Comparison of RT-qPCR data with RNA-Seq data}

The $\log 2$ transformed fold change (FC) values of gene expression levels between KTCN and non-KTCN samples were calculated for RT-qPCR and previously reported RNA-Seq data, GSE77938 (Kabza et al., 2017). To calculate the log2 FC values based on RNA-Seq results, gene expression data from both discovery and replication RNA-Seq experiments were analyzed together. Briefly, Illumina adapter sequences, poor quality regions (average Phred quality score below 5), and sequences matching human rRNAs were removed from the sequenced short reads using the BBDuk2 program from the BBTools package (http://jgi.doe.gov/data-and-tools/bbtools). Filtered reads shorter than $50 \mathrm{bp}$ were discarded. The expression values of known genes and transcripts from GENCODE 25 annotations (Ensembl 87) were estimated using Salmon with sequence-specific and GC content bias correction enabled. RNA-Seq fold change values were obtained from limma package using a previously published protocol (Ritchie et al., 2015; Patro, Duggal \& Kingsford, 2015; Law et al., 2016; Kabza et al., 2017). Pearson correlations between $\log 2 \mathrm{FC}$ values for selected genes obtained from RT-qPCR and RNA-Seq data were evaluated using the R package (R Development Core Team, 2008).

\section{Results}

Differential expression analysis

Nine of 45 studied genes (BMP4, PPP2R2B, SMAD9, IL6, IL17B, PLEKHA7, FGF14, $M O R C 1$, and $S Y N 2)$ had high frequency $(>8.5 \%)$ of missing data and were excluded from further analyses. In result, gene expression profiles were assessed in six KTCN and six non-KTCN corneas for 36 candidate KTCN genes (Table 1).

The analysis of RT-qPCR data showed that 23 genes had decreased expression level in the KTCN patients compared to the non-KTCN individuals, including six genes (CTGF, ZNF469, 
$183 T G F B 3, C O L 5 A 2, S M A D 7$, and $S P A R C)$ with $\log 2 \mathrm{FC}$ values lower than -2.0 and six genes $(L O X$, 184 TEAD2, TEAD4, TGFB1, TGFBR2, and ZEB1) with log2 FC values between -1.0 and -1.99 (Table 185 1). Twelve genes presented with increased expression, including SLC4A11 and TGFBI with $\log 2$ 186 FC values greater than 1.0 (Table 1). No difference between the level of CTNNB1 transcripts was 187 observed for KTCN and non-KTCN individuals. Relative gene expression is presented in Table 188 S3.

Sample clustering performed based on all differentially expressed genes showed almost clear separation of KTCN and non-KTCN clusters. Only one non-KTCN sample (KR49) was misclassified in the KTCN cluster (Figure 1).

Comparison of RT-qPCR data with RNA-seq data

The $\log 2$ FC values for 36 genes obtained during the RT-qPCR and RNA-Seq showed a strong correlation between the two sets of results. The Pearson correlation coefficient (r) was 0.91 (Figure 2).

\section{Discussion}

Differences in transcriptomic profiles between various cells and tissues play an essential role in the normal functioning of the human body (Frith, Pheasant \& Mattick, 2005; Cummings et al., 2017). During the last few years, numerous transcriptome studies have been performed to understand how the changes in gene expression may influence different phenotypes, including KTCN (Nielsen et al., 2003; Macé et al., 2011; Joseph, Srivastava \& Pfister, 2016; Kabza et al., 2017).

The results of RNA-Seq-based transcriptomic profiling of human corneas suggested that downregulation of collagens and other genes encoding ECM components might be involved in KTCN etiology as it can lead to the reduction of the mechanical stability of affected tissues (Kabza 
206 et al., 2017). Moreover, it was postulated that the previously observed decreased level of collagen

207 genes in KTCN corneas might be a result of downregulation of connective tissue growth factor

$208(C T G F)$ and its modulators, which are involved in the TGF- $\beta$, Hippo, and Wnt signaling pathways

209 (Kabza et al., 2017). Interestingly, changed expression patterns of the core elements of these three

210 biological pathways in KTCN corneas were confirmed in the present RT-qPCR study.

211 Three transforming growth factor beta (TGF- $\beta$ ) isoforms, TGFB1, TGFB2, and TGFB3,

212 through binding to their receptors (TGFBR1, TGFBR2), initiate signaling that regulates the

213 assembly of ECM. While TGFB1 and TGFB2 act as stimulators of a profibrotic response in the

214 injured cornea, TGFB3 is known for its antifibrotic effect (Priyadarsini et al., 2015). TGF- $\beta$

215 signaling stimulates the downstream synthesis of CTGF. As a result, corneal cells are activated

216 and begin to produce different types of collagen and other ECM components (Blalock et al., 2003).

217 The levels of $T G F B 1, T G F B 3, T G F B R 2, C O L 5 A 2$, and CTGF were decreased in this study

218 confirming that previously observed low expression of genes encoding major ECM components,

219 including collagens, may be an effect of TGF- $\beta$ signaling alteration in KTCN (Joseph, Srivastava

220 \& Pfister, 2016; Kabza et al., 2017).

221 The TGF- $\beta$ pathway is controlled by SMAD proteins, including SMAD family member 7 ,

222 which through binding to TGF- $\beta$ receptors, leads to an inhibition in TGF- $\beta$ signaling (Yan, Liu \&

223 Chen, 2009). Interestingly, TGF- $\beta$ transcriptional responses could also be regulated by non-Smad

224 pathways (Zhang, 2009). That could explain decreased SMAD7 level and increased expression of

225 TGFBI, a downstream effector of TGF- $\beta$, at the same time. The TGFBI is a significant component

226 of human corneal stroma involved in cell adhesion and migration, which is induced by its

227 interaction with several ECM elements, including collagens (Runager, Enghild \& Klintworth, 228 2008). TGFBI variants have been frequently identified in patients with corneal dystrophies (Chao- 
229 Shern et al., 2019), as well as KTCN (Guan et al., 2012). While a significant upregulation of

230 TGFBI in KTCN patients compared to control individuals was also detected previously

231 (Bykhovskaya et al., 2016a), in most transcriptomic or proteomic studies the level of TGFBI in

232 KTCN tissues was decreased (Takács et al., 1999; Zhao et al., 2002). Since different material was

233 used in these mentioned analyses (whole corneas, corneal buttons, or corneal stroma), the observed

234 results could vary because of the influence of other cells on the tissue expression. More studies are 235 needed to verify this data.

236 It is known that TGF- $\beta$ is integrated into higher-order networks and crosstalk between

237 TGF- $\beta$, Wnt and Hippo signaling regulates the outcome of signaling activity (Attisano \& Wrana,

238 2013). The Hippo molecular cascade is involved in controlling the eye size, and TEA domain

239 transcription factors, encoded by the TEAD2 and TEAD4 genes, play an essential role in its

240 regulation (Yu \& Guan, 2013). Moreover, TEAD2 and TEAD4 transcription factors integrate

241 Hippo and Wnt pathways at the nucleus through cooperation with YAP and TAZ molecules

242 (Attisano \& Wrana, 2013). Decreased level of TEAD2 and TEAD4, observed in this study in KTCN

243 corneas, supports our previous data. Also, it indicates that abnormal expression of particular

244 elements of the TGF- $\beta$, Hippo, and Wnt pathways might alter signaling crosstalk between these

245 cascades in KTCN. Of note, our recent ES findings showed the accumulation of variants in several

246 genes from Wnt signaling and/or focal adhesion pathways, deregulated in KTCN, further

247 supporting possible involvement of these genes in disease etiology (Karolak et al., 2020).

248 Apart from genes involved in the pathways mentioned above, selected as candidates for

249 KTCN based on solely transcriptome study, there are numerous putative KTCN genes, which are

250 revealed using linkage analyses, GWAS, or ES (Karolak \& Gajecka, 2017). The level of these

251 genes expression was also evaluated using RNA-Seq (Kabza et al., 2017). However, their 
252 significance in KTCN could not be clearly defined due to contradictory findings in genomic

253 studies. Thus, in this study, 19 candidate KTCN genes were selected for re-evaluation using RT-

254 qPCR. In KTCN corneas compared to non-KTCN corneas, we observed altered expression profiles

255 of a few of them, including ZNF469, SPARC, and $L O X$.

256 The ZNF469 gene was initially associated with central corneal thickness (CCT), which is

257 abnormal in KTCN or corneal dystrophies (Lu et al., 2010, 2013; Vitart et al., 2010) and now is

258 one of the most discussed KTCN genes. Another KTCN candidate, the SPARC gene, is positioned

259 in the $5 q 32-q 33$ region that shows a suggestive linkage with $\mathrm{KTCN}$ in previous studies (Bisceglia

260 et al., 2009). A lot of single nucleotide variants in ZNF469 (Vincent et al., 2014; Lechner et al.,

261 2014; Davidson et al., 2015; Karolak et al., 2016b; Kalantan et al., 2017; Lucas et al., 2017) and

262 SPARC (De Bonis et al., 2011) have been identified in KTCN patients. However, the role of both

263 genes in determining the disease has not been definitively clarified based on mutational studies

264 and it should be further evaluated in the KTCN context. The proteins encoded by both ZNF469

265 and SPARC regulate ECM production and remodeling and participate in collagen homeostasis in

266 the human cornea (Bradshaw et al., 2003; Burkitt Wright et al., 2011). Thus, the observed

267 decreased expression of both genes in KTCN corneas might also partially explain previously

268 identified downregulation of genes encoding ECM components and might shed more light on the

269 role of these genes in KTCN.

270 The $L O X$ gene encodes an enzyme responsible for collagen cross-linking in the cornea and

271 is one of the well-studied genes in KTCN. It is mapped within 5q21 region linked to KTCN in

272 Italian population (Bisceglia et al., 2009). While the first mutational screening of $L O X$ has not

273 confirmed the involvement of $L O X$ variants in $\mathrm{KTCN}$, evidence of a genetic association between

$274 \mathrm{KTCN}$ and common SNVs located in the $L O X$ gene has been revealed in Caucasian (Bykhovskaya 
275 et al., 2012), Czech (Dudakova et al., 2015), Iranian (Hasanian-Langroudi et al., 2015), Brazilian

276 (Gadelha et al., 2020), and Han Chinese (Xu et al., 2020) KTCN patients. In our study, the level

277 of $L O X$ was decreased in KTCN corneas. Previously, the reduced expression or activity of $L O X$

278 have been found in the cultured keratoconic fibroblasts (Dudakova et al., 2012), KTCN corneal

279 epithelium and tears (Shetty et al., 2015), the cone apex of KTCN patients (Pahuja et al., 2016), as

280 well as in the whole KTCN corneas (Kabza et al., 2017). The observed decreased level of LOX

281 might affect the reduction of collagen cross-linking in the corneal stroma, leading to the thinning

282 of the cornea (Dudakova et al., 2012; Pahuja et al., 2016).

283 Among the genes with detected increased expression in KTCN, the most interesting

284 candidates are TGFBI, discussed above, and SLC4A11. Sodium bicarbonate transporter-like

285 protein 11 (SLC4A11), functioning as an electrogenic $\mathrm{Na}^{+}$-coupled borate co-transporter, is

286 involved in the stimulation of cell growth and proliferation via borate-dependent mitogen-activated

287 protein kinase activation (Romero, Fulton \& Boron, 2004; Park et al., 2004). SLC4A11 has been

288 previously reported as involved in KTCN and its observed deregulation supports the previous

289 findings (Guan et al., 2012; Nowak et al., 2013). However, the mechanism through which they

290 influence the KTCN development is unknown and further research should be performed to

291 interpret the obtained data.

292 In our study, hierarchical cluster analyses of RT-qPCR gene expression data correctly

293 grouped the majority of KTCN and non-KTCN corneas. However, one non-KTCN sample (KR49)

294 was misclassified with the KTCN cluster. As was hypothesized previously, the observed 295 misclassification might be the consequence of the high heterogeneity of the control group, which

296 could be recognized as a study limitation (Kabza et al., 2017). As it was not possible to obtain

297 "healthy" corneas from living donors, corneal tissues have been ascertained from control 
298 individuals with different ocular phenotypes, including corneal ulcer, bullous keratopathy, and

299 history of keratitis and ocular trauma. All of these diseases can result in corneal scarring. The

300 misclassified KR49 cornea was obtained from a 38-years-old man referred for corneal

301 transplantation after ocular trauma and had no other eye diseases. The tissue homeostasis during

302 corneal scarring could be altered due to activation and or inhibition of several molecular pathways.

303 Depending on the stage of wound healing that results in ocular scarring, the gene expression of 304 particular genes could be abnormal. Thus, we hypothesize that this could lead to the 305 misclassification of our patient in hierarchical cluster analyses based on gene expression profiles.

306 In addition, KR49 patient was the youngest individual among control participants, which could 307 also be a potential confounding factor.

Another aspect of our study was to validate the RNA-Seq experiment performed previously in the same (except for KR49) human KTCN and non-KTCN corneas. The comparison of RNA-

Seq data with results obtained from current RT-qPCR analysis showed a strong correlation between the two sets of data, indicating that the selected 36 genes were not false positives and suggesting high concordance between both methods. However, protein-based assays would provide further validity to observed findings.

\section{Conclusions}

In conclusion, in the present study, we have assessed the expression of 36 candidate genes across KTCN and non-KTCN human corneas to further investigate their contribution in KTCN etiology. We confirmed differential expression of 35 genes, including core elements of recently postulated KTCN pathways: the ECM formation, Hippo, and Wnt signaling. We found that the deregulation of genes identified using RNA-Seq was not incidental, and selected candidate genes were not false positives. Our results also showed abnormal expression of several other genes, such 
321 as $L O X, S P A R C, Z N F 469$, or $T G F B I$, in which single nucleotide variants have been frequently

322 identified in KTCN individuals. Although the obtained results partially explain the molecular basis

323 of KTCN etiology, our understanding of this complex disease is still rudimentary. To address this

324 gap, further studies in a larger group of patients should be performed.

\section{References}

Abu-Amero KK, Al-Muammar AM, Kondkar AA. 2014. Genetics of keratoconus: where do we stand? Journal of Ophthalmology 2014:641708. DOI: 10.1155/2014/641708.

Attisano L, Wrana JL. 2013. Signal integration in TGF- $\beta$, WNT, and Hippo pathways. F1000prime Reports 5:17. DOI: 10.12703/P5-17.

Barbaro V, Di Iorio E, Ferrari S, Bisceglia L, Ruzza A, De Luca M, Pellegrini G. 2006. Expression of VSX1 in human corneal keratocytes during differentiation into myofibroblasts in response to wound healing. Investigative Ophthalmology \& Visual Science 47:5243-5250. DOI: 10.1167/iovs.06-0185.

Bisceglia L, De Bonis P, Pizzicoli C, Fischetti L, Laborante A, Di Perna M, Giuliani F, Delle Noci N, Buzzonetti L, Zelante L. 2009. Linkage analysis in keratoconus: replication of locus 5q21.2 and identification of other suggestive Loci. Investigative Ophthalmology \& Visual Science 50:1081-1086. DOI: 10.1167/iovs.08-2382.

Blalock TD, Duncan MR, Varela JC, Goldstein MH, Tuli SS, Grotendorst GR, Schultz GS. 2003. Connective tissue growth factor expression and action in human corneal fibroblast cultures and rat corneas after photorefractive keratectomy. Investigative Ophthalmology \& Visual Science 44:1879-1887. DOI: 10.1167/iovs.02-0860. 
343 Bradshaw AD, Puolakkainen P, Dasgupta J, Davidson JM, Wight TN, Helene Sage E. 2003. SPARC-null mice display abnormalities in the dermis characterized by decreased collagen fibril diameter and reduced tensile strength. The Journal of Investigative Dermatology 120:949-955. DOI: 10.1046/j.1523-1747.2003.12241.x.

Brancati F, Valente EM, Sarkozy A, Fehèr J, Castori M, Del Duca P, Mingarelli R, Pizzuti A, Dallapiccola B. 2004. A locus for autosomal dominant keratoconus maps to human chromosome 3p14-q13. Journal of Medical Genetics 41:188-192.

Burdon KP, Coster DJ, Charlesworth JC, Mills RA, Laurie KJ, Giunta C, Hewitt AW, Latimer P, Craig JE. 2008. Apparent autosomal dominant keratoconus in a large Australian pedigree accounted for by digenic inheritance of two novel loci. Human Genetics 124:379-386. DOI: $10.1007 / \mathrm{s} 00439-008-0555-\mathrm{z}$.

Burdon KP, Macgregor S, Bykhovskaya Y, Javadiyan S, Li X, Laurie KJ, Muszynska D, Lindsay R, Lechner J, Haritunians T, Henders AK, Dash D, Siscovick D, Anand S, Aldave A, Coster DJ, Szczotka-Flynn L, Mills RA, Iyengar SK, Taylor KD, Phillips T, Montgomery GW, Rotter JI, Hewitt AW, Sharma S, Rabinowitz YS, Willoughby C, Craig JE. 2011. Association of polymorphisms in the hepatocyte growth factor gene promoter with keratoconus. Investigative Ophthalmology \& Visual Science 52:8514-8519. DOI: 10.1167/iovs.11-8261.

Burkitt Wright EMM, Spencer HL, Daly SB, Manson FDC, Zeef LAH, Urquhart J, Zoppi N, Bonshek R, Tosounidis I, Mohan M, Madden C, Dodds A, Chandler KE, Banka S, Au L, Clayton-Smith J, Khan N, Biesecker LG, Wilson M, Rohrbach M, Colombi M, Giunta C, Black GCM. 2011. Mutations in PRDM5 in Brittle Cornea Syndrome Identify a Pathway 
Regulating Extracellular Matrix Development and Maintenance. American Journal of Human Genetics 88:767-777. DOI: 10.1016/j.ajhg.2011.05.007.

Bykhovskaya Y, Gromova A, Makarenkova HP, Rabinowitz YS. 2016a. Abnormal regulation of extracellular matrix and adhesion molecules in corneas of patients with keratoconus. International Journal of Keratoconus and Ectatic Corneal Diseases 5:63-70. DOI: 10.5005/jp-journals-10025-1123.

Bykhovskaya Y, Li X, Epifantseva I, Haritunians T, Siscovick D, Aldave A, Szczotka-Flynn L, Iyengar SK, Taylor KD, Rotter JI, Rabinowitz YS. 2012. Variation in the lysyl oxidase $(L O X)$ gene is associated with keratoconus in family-based and case-control studies. Investigative Ophthalmology \& Visual Science 53:4152-4157. DOI: 10.1167/iovs.119268.

Bykhovskaya Y, Li X, Taylor KD, Haritunians T, Rotter JI, Rabinowitz YS. 2016b. Linkage Analysis of High-density SNPs Confirms Keratoconus Locus at 5q Chromosomal Region. Ophthalmic Genetics 37:109-110. DOI: 10.3109/13816810.2014.889172.

Bykhovskaya Y, Margines B, Rabinowitz YS. 2016. Genetics in Keratoconus: where are we? Eye and Vision (London, England) 3:16. DOI: 10.1186/s40662-016-0047-5.

Chao-Shern C, DeDionisio LA, Jang J-H, Chan CC, Thompson V, Christie K, Nesbit MA, McMullen CBT. 2019. Evaluation of TGFBI corneal dystrophy and molecular diagnostic testing. Eye 33:874-881. DOI: 10.1038/s41433-019-0346-x.

Cummings BB, Marshall JL, Tukiainen T, Lek M, Donkervoort S, Foley AR, Bolduc V, Waddell LB, Sandaradura SA, O’Grady GL, Estrella E, Reddy HM, Zhao F, Weisburd B, Karczewski KJ, O’Donnell-Luria AH, Birnbaum D, Sarkozy A, Hu Y, Gonorazky H, Claeys K, Joshi H, Bournazos A, Oates EC, Ghaoui R, Davis MR, Laing NG, Topf A, 
Genotype-Tissue Expression Consortium, Kang PB, Beggs AH, North KN, Straub V,

Dowling JJ, Muntoni F, Clarke NF, Cooper ST, Bönnemann CG, MacArthur DG. 2017. Improving genetic diagnosis in Mendelian disease with transcriptome sequencing. Science Translational Medicine 9. DOI: 10.1126/scitranslmed.aal5209.

392

394

Davidson AE, Borasio E, Liskova P, Khan AO, Hassan H, Cheetham ME, Plagnol V, Alkuraya FS, Tuft SJ, Hardcastle AJ. 2015. Brittle cornea syndrome ZNF469 mutation carrier phenotype and segregation analysis of rare ZNF469 variants in familial keratoconus. Investigative Ophthalmology \& Visual Science 56:578-586. DOI: 10.1167/iovs.14-15792.

De Bonis P, Laborante A, Pizzicoli C, Stallone R, Barbano R, Longo C, Mazzilli E, Zelante L, Bisceglia L. 2011. Mutational screening of VSX1, SPARC, SOD1, LOX, and TIMP3 in keratoconus. Molecular Vision 17:2482-2494.

Dudakova L, Liskova P, Trojek T, Palos M, Kalasova S, Jirsova K. 2012. Changes in lysyl oxidase (LOX) distribution and its decreased activity in keratoconus corneas. Experimental Eye Research 104:74-81. DOI: 10.1016/j.exer.2012.09.005.

Dudakova L, Palos M, Jirsova K, Stranecky V, Krepelova A, Hysi PG, Liskova P. 2015. Validation of rs2956540:G>C and rs3735520:G>A association with keratoconus in a population of European descent. European journal of human genetics 23:1581-1583. DOI: 10.1038/ejhg.2015.28.

Frith MC, Pheasant M, Mattick JS. 2005. The amazing complexity of the human transcriptome. European journal of human genetics 13:894-897. DOI: 10.1038/sj.ejhg.5201459.

Fullerton J, Paprocki P, Foote S, Mackey DA, Williamson R, Forrest S. 2002. Identity-by-descent approach to gene localisation in eight individuals affected by keratoconus from north-west Tasmania, Australia. Human Genetics 110:462-470. DOI: 10.1007/s00439-002-0705-7. 
411 Gadelha DNB, Feitosa AFB, da Silva RG, Antunes LT, Muniz MC, de Oliveira MA, Andrade D 412 de O, da Paz Silva NM, Cronemberger S, Schamber-Reis BLF. 2020. Screening for Novel

413

414

415

416

417

418

419

420

421

422

423

424

425

426

427

428

429

430

431

432

433 $L O X$ and SOD1 Variants in Keratoconus Patients from Brazil. Journal of Ophthalmic \& Vision Research 15:138-148. DOI: 10.18502/jovr.v15i2.6730.

Gajecka M, Radhakrishna U, Winters D, Nath SK, Rydzanicz M, Ratnamala U, Ewing K, Molinari A, Pitarque JA, Lee K, Leal SM, Bejjani BA. 2009. Localization of a gene for keratoconus to a 5.6-Mb interval on 13q32. Investigative Ophthalmology \& Visual Science 50:15311539. DOI: $10.1167 /$ iovs.08-2173.

Godefrooij DA, de Wit GA, Uiterwaal CS, Imhof SM, Wisse RPL. 2016. Age-specific incidence and prevalence of keratoconus: a nationwide registration study. American Journal of Ophthalmology. DOI: 10.1016/j.ajo.2016.12.015.

Guan T, Liu C, Ma Z, Ding S. 2012. The point mutation and polymorphism in keratoconus candidate gene TGFBI in Chinese population. Gene 503:137-139. DOI: 10.1016/j.gene.2012.04.061.

Hameed A, Khaliq S, Ismail M, Anwar K, Ebenezer ND, Jordan T, Mehdi SQ, Payne AM, Bhattacharya SS. 2000. A novel locus for Leber congenital amaurosis (LCA4) with anterior keratoconus mapping to chromosome 17p13. Investigative Ophthalmology \& Visual Science 41:629-633.

Hasanian-Langroudi F, Saravani R, Validad M-H, Bahari G, Yari D. 2015. Association of Lysyl oxidase $(L O X)$ Polymorphisms with the Risk of Keratoconus in an Iranian Population. Ophthalmic Genetics 36:309-314. DOI: 10.3109/13816810.2014.881507.

Héon E, Greenberg A, Kopp KK, Rootman D, Vincent AL, Billingsley G, Priston M, Dorval KM, Chow RL, McInnes RR, Heathcote G, Westall C, Sutphin JE, Semina E, Bremner R, Stone 
434

435

436

437

438

439

440

441

442

443

444

445

446

447

448

449

450

451

452

453

454

455

EM. 2002. VSX1: a gene for posterior polymorphous dystrophy and keratoconus. Human Molecular Genetics 11:1029-1036.

Hughes AE, Dash DP, Jackson AJ, Frazer DG, Silvestri G. 2003. Familial keratoconus with cataract: linkage to the long arm of chromosome 15 and exclusion of candidate genes. Investigative Ophthalmology \& Visual Science 44:5063-5066.

Hutchings H, Ginisty H, Le Gallo M, Levy D, Stoësser F, Rouland JF, Arné JL, Lalaux MH, Calvas P, Roth MP, Hovnanian A, Malecaze F. 2005. Identification of a new locus for isolated familial keratoconus at 2p24. Journal of Medical Genetics 42:88-94. DOI: 10.1136/jmg.2004.022103.

Joseph R, Srivastava OP, Pfister RR. 2016. Modeling Keratoconus Using Induced Pluripotent Stem Cells. Investigative Ophthalmology \& Visual Science 57:3685-3697. DOI: 10.1167/iovs.16-19105.

Kabza M, Karolak JA, Rydzanicz M, Szcześniak MW, Nowak DM, Ginter-Matuszewska B, Polakowski P, Ploski R, Szaflik JP, Gajecka M. 2017. Collagen synthesis disruption and downregulation of core elements of TGF- $\beta$, Hippo, and Wnt pathways in keratoconus corneas. European journal of human genetics 25:582-590. DOI: 10.1038/ejhg.2017.4.

Kalantan H, Kondkar AA, Sultan T, Azad TA, Alsabaani NA, AlQahtani MA, Almummar A, Liu Y, Abu-Amero KK. 2017. Polymorphism rs13334190 in zinc finger protein 469 (ZNF469) is not a risk factor for keratoconus in a Saudi cohort. BMC research notes 10:652. DOI: 10.1186/s13104-017-2996-8.

Karolak JA, Gajecka M. 2017. Genomic strategies to understand causes of keratoconus. Molecular genetics and genomics: $M G G$ 292:251-269. DOI: 10.1007/s00438-016-1283-z. 
456 Karolak JA, Gambin T, Pitarque JA, Molinari A, Jhangiani S, Stankiewicz P, Lupski JR, Gajecka

457

458

459

460

461

462

463

464

465

466

467

468

469

470

471

472

473

474

475

476

477

478

M. 2016a. Variants in SKP1, PROB1, and $I L 17 B$ genes at keratoconus 5q31.1-q35.3 susceptibility locus identified by whole-exome sequencing. European journal of human genetics 25:73-78. DOI: 10.1038/ejhg.2016.130.

Karolak JA, Gambin T, Rydzanicz M, Polakowski P, Ploski R, Szaflik JP, Gajecka M. 2020. Accumulation of sequence variants in genes of Wnt signaling and focal adhesion pathways in human corneas further explains their involvement in keratoconus. PeerJ:8:e8982. DOI: https://doi.org/10.7717/peerj.8982.

Karolak JA, Gambin T, Rydzanicz M, Szaflik JP, Polakowski P, Frajdenberg A, Mrugacz M, Podfigurna-Musielak M, Stankiewicz P, Gajecka M. 2016b. Evidence against ZNF469 being causative for keratoconus in Polish patients. Acta Ophthalmologica 94:289-294. DOI: $10.1111 /$ aos.12968.

Karolak JA, Kulinska K, Nowak DM, Pitarque JA, Molinari A, Rydzanicz M, Bejjani BA, Gajecka M. 2011. Sequence variants in COL4A1 and COL4A2 genes in Ecuadorian families with keratoconus. Molecular Vision 17:827-843.

Khaled ML, Bykhovskaya Y, Yablonski SER, Li H, Drewry MD, Aboobakar IF, Estes A, Gao XR, Stamer WD, Xu H, Allingham RR, Hauser MA, Rabinowitz YS, Liu Y. 2018. Differential Expression of Coding and Long Noncoding RNAs in Keratoconus-Affected Corneas. Investigative Ophthalmology \& Visual Science 59:2717-2728. DOI: 10.1167/iovs.18-24267.

Law CW, Alhamdoosh M, Su S, Smyth GK, Ritchie ME. 2016. RNA-seq analysis is easy as 1-23 with limma, Glimma and edgeR. F1000Research 5:1408. DOI: 10.12688/f1000research.9005.2.

Peer] reviewing PDF | (2020:04:48238:1:0:NEW 13 Jul 2020) 
479 Lechner J, Dash DP, Muszynska D, Hosseini M, Segev F, George S, Frazer DG, Moore JE, Kaye 480 SB, Young T, Simpson DA, Churchill AJ, Héon E, Willoughby CE. 2013. Mutational

481

482

483

484

485

486

487

488

489

490

491

492

493

494

495

496

497

498

499

500 spectrum of the ZEB1 gene in corneal dystrophies supports a genotype-phenotype correlation. Investigative Ophthalmology \& Visual Science 54:3215-3223. DOI: 10.1167/iovs.13-11781.

Lechner J, Porter LF, Rice A, Vitart V, Armstrong DJ, Schorderet DF, Munier FL, Wright AF, Inglehearn CF, Black GC, Simpson DA, Manson F, Willoughby CE. 2014. Enrichment of pathogenic alleles in the brittle cornea gene, ZNF469, in keratoconus. Human Molecular Genetics 23:5527-5535. DOI: 10.1093/hmg/ddu253.

Léoni-Mesplié S, Mortemousque B, Touboul D, Malet F, Praud D, Mesplié N, Colin J. 2012. Scalability and severity of keratoconus in children. American Journal of Ophthalmology 154:56-62.e1. DOI: 10.1016/j.ajo.2012.01.025.

Li X, Rabinowitz YS, Tang YG, Picornell Y, Taylor KD, Hu M, Yang H. 2006. Two-stage genome-wide linkage scan in keratoconus sib pair families. Investigative Ophthalmology \& Visual Science 47:3791-3795. DOI: 10.1167/iovs.06-0214.

Liskova P, Hysi PG, Waseem N, Ebenezer ND, Bhattacharya SS, Tuft SJ. 2010. Evidence for keratoconus susceptibility locus on chromosome 14: a genome-wide linkage screen using single-nucleotide polymorphism markers. Archives of Ophthalmology (Chicago, Ill.: 1960) 128:1191-1195. DOI: 10.1001/archophthalmol.2010.200.

Loukovitis E, Sfakianakis K, Syrmakesi P, Tsotridou E, Orfanidou M, Bakaloudi DR, Stoila M, Kozei A, Koronis S, Zachariadis Z, Tranos P, Kozeis N, Balidis M, Gatzioufas Z, Fiska A, Anogeianakis G. 2018. Genetic Aspects of Keratoconus: A Literature Review Exploring 
Potential Genetic Contributions and Possible Genetic Relationships with Comorbidities. Ophthalmology and Therapy 7:263-292. DOI: 10.1007/s40123-018-0144-8.

503

504

505

506

507

Lu Y, Dimasi DP, Hysi PG, Hewitt AW, Burdon KP, Toh T, Ruddle JB, Li YJ, Mitchell P, Healey PR, Montgomery GW, Hansell N, Spector TD, Martin NG, Young TL, Hammond CJ, Macgregor S, Craig JE, Mackey DA. 2010. Common genetic variants near the Brittle Cornea Syndrome locus ZNF469 influence the blinding disease risk factor central corneal thickness. PLoS genetics 6:e1000947. DOI: 10.1371/journal.pgen.1000947.

Lu Y, Vitart V, Burdon KP, Khor CC, Bykhovskaya Y, Mirshahi A, Hewitt AW, Koehn D, Hysi PG, Ramdas WD, Zeller T, Vithana EN, Cornes BK, Tay W-T, Tai ES, Cheng C-Y, Liu J, Foo J-N, Saw SM, Thorleifsson G, Stefansson K, Dimasi DP, Mills RA, Mountain J, Ang W, Hoehn R, Verhoeven VJM, Grus F, Wolfs R, Castagne R, Lackner KJ, Springelkamp H, Yang J, Jonasson F, Leung DYL, Chen LJ, Tham CCY, Rudan I, Vatavuk Z, Hayward C, Gibson J, Cree AJ, MacLeod A, Ennis S, Polasek O, Campbell H, Wilson JF, Viswanathan AC, Fleck B, Li X, Siscovick D, Taylor KD, Rotter JI, Yazar S, Ulmer M, Li J, Yaspan BL, Ozel AB, Richards JE, Moroi SE, Haines JL, Kang JH, Pasquale LR, Allingham RR, Ashley-Koch A, NEIGHBOR Consortium, Mitchell P, Wang JJ, Wright AF, Pennell C, Spector TD, Young TL, Klaver CCW, Martin NG, Montgomery GW, Anderson MG, Aung T, Willoughby CE, Wiggs JL, Pang CP, Thorsteinsdottir U, Lotery AJ, Hammond CJ, van Duijn CM, Hauser MA, Rabinowitz YS, Pfeiffer N, Mackey DA, Craig JE, Macgregor S, Wong TY. 2013. Genome-wide association analyses identify multiple loci associated with central corneal thickness and keratoconus. Nature Genetics 45:155-163. DOI: $10.1038 / n g .2506$. 
523 Lucas SEM, Burdon KP. 2020. Genetic and Environmental Risk Factors for Keratoconus. Annual 524 Review of Vision Science. DOI: 10.1146/annurev-vision-121219-081723.

525 Lucas SEM, Zhou T, Blackburn NB, Mills RA, Ellis J, Leo P, Souzeau E, Ridge B, Charlesworth 526 JC, Brown MA, Lindsay R, Craig JE, Burdon KP. 2017. Rare, Potentially Pathogenic Variants in ZNF469 Are Not Enriched in Keratoconus in a Large Australian Cohort of European Descent. Investigative Ophthalmology \& Visual Science 58:6248-6256. DOI: 10.1167/iovs.17-22417.

Macé M, Galiacy SD, Erraud A, Mejía JE, Etchevers H, Allouche M, Desjardins L, Calvas P, 531 Malecaze F. 2011. Comparative transcriptome and network biology analyses demonstrate antiproliferative and hyperapoptotic phenotypes in human keratoconus corneas. Investigative Ophthalmology \& Visual Science 52:6181-6191. DOI: 10.1167/iovs.10-

Naderan M, Rajabi MT, Zarrinbakhsh P, Naderan M, Bakhshi A. 2016. Association between 536 Family History and Keratoconus Severity. Current Eye Research 41:1414-1418. DOI: 10.3109/02713683.2015.1128553.

Nielsen K, Birkenkamp-Demtröder K, Ehlers N, Orntoft TF. 2003. Identification of differentially expressed genes in keratoconus epithelium analyzed on microarrays. Investigative Ophthalmology \& Visual Science 44:2466-2476.

Nowak DM, Gajecka M. 2011. The genetics of keratoconus. Middle East African Journal of Ophthalmology 18:2-6. DOI: 10.4103/0974-9233.75876.

Nowak DM, Karolak JA, Kubiak J, Gut M, Pitarque JA, Molinari A, Bejjani BA, Gajecka M. 2013. Substitution at $I L 1 R N$ and deletion at $S L C 4 A 11$ segregating with phenotype in 
familial keratoconus. Investigative Ophthalmology \& Visual Science 54:2207-2215. DOI:

546 10.1167/iovs.13-11592.

547

548

549

550

551

552

553

554

555

556

557

558

559

560

561

562

563

564

565

566

567

Pahuja N, Kumar NR, Shroff R, Shetty R, Nuijts RMMA, Ghosh A, Sinha-Roy A, Chaurasia SS, Mohan RR, Ghosh A. 2016. Differential Molecular Expression of Extracellular Matrix and Inflammatory Genes at the Corneal Cone Apex Drives Focal Weakening in Keratoconus. Investigative Ophthalmology \& Visual Science 57:5372-5382. DOI: 10.1167/iovs.1619677.

Park M, Li Q, Shcheynikov N, Zeng W, Muallem S. 2004. NaBC1 is a ubiquitous electrogenic $\mathrm{Na}+$-coupled borate transporter essential for cellular boron homeostasis and cell growth and proliferation. Molecular Cell 16:331-341. DOI: 10.1016/j.molcel.2004.09.030.

Patro R, Duggal G, Kingsford C. 2015. Salmon: Accurate, Versatile and Ultrafast Quantification from RNA-seq Data using Lightweight-Alignment. bioRxiv. DOI: 10.1101/021592.

Priyadarsini S, McKay TB, Sarker-Nag A, Karamichos D. 2015. Keratoconus in vitro and the key players of the TGF- $\beta$ pathway. Molecular Vision 21:577-588.

R Development Core Team. 2008. R: A language and environment for statistical computing. $R$ Foundation for Statistical Computing, Vienna, Austria ISBN 3-900051-07-0.

Rabinowitz YS. 1998. Keratoconus. Survey of Ophthalmology 42:297-319.

Ritchie ME, Phipson B, Wu D, Hu Y, Law CW, Shi W, Smyth GK. 2015. limma powers differential expression analyses for RNA-sequencing and microarray studies. Nucleic Acids Research 43:e47. DOI: 10.1093/nar/gkv007.

Romero MF, Fulton CM, Boron WF. 2004. The SLC4 family of HCO 3 - transporters. Pflugers Archiv: European Journal of Physiology 447:495-509. DOI: 10.1007/s00424-003-11802. 
568 Rosenfeld JA, Drautz JM, Clericuzio CL, Cushing T, Raskin S, Martin J, Tervo RC, Pitarque JA, 569 Nowak DM, Karolak JA, Lamb AN, Schultz RA, Ballif BC, Bejjani BA, Gajecka M,

570

571

572

573

574

575

576

577

578

579

580

581

582

583

584

585

586

587

588

589

Shaffer LG. 2011. Deletions and duplications of developmental pathway genes in 5q31 contribute to abnormal phenotypes. American Journal of Medical Genetics. Part A 155A:1906-1916. DOI: 10.1002/ajmg.a.34100.

Runager K, Enghild JJ, Klintworth GK. 2008. Focus on molecules: Transforming growth factor beta induced protein (TGFBIp). Experimental Eye Research 87:298-299. DOI: 10.1016/j.exer.2007.12.001.

Sahebjada S, Schache M, Richardson AJ, Snibson G, Daniell M, Baird PN. 2014. Association of the hepatocyte growth factor gene with keratoconus in an Australian population. PloS One 9:e84067. DOI: 10.1371/journal.pone.0084067.

Sahebjada S, Schache M, Richardson AJ, Snibson G, MacGregor S, Daniell M, Baird PN. 2013. Evaluating the association between keratoconus and the corneal thickness genes in an independent Australian population. Investigative Ophthalmology \& Visual Science 54:8224-8228. DOI: 10.1167/iovs.13-12982.

Sharif R, Khaled ML, McKay TB, Liu Y, Karamichos D. 2019. Transcriptional profiling of corneal stromal cells derived from patients with keratoconus. Scientific Reports 9:12567. DOI: 10.1038/s41598-019-48983-8.

Shetty R, Sathyanarayanamoorthy A, Ramachandra RA, Arora V, Ghosh A, Srivatsa PR, Pahuja N, Nuijts RMMA, Sinha-Roy A, Mohan RR, Ghosh A. 2015. Attenuation of lysyl oxidase and collagen gene expression in keratoconus patient corneal epithelium corresponds to disease severity. Molecular Vision 21:12-25.

Peer) reviewing PDF | (2020:04:48238:1:0:NEW 13 Jul 2020) 
590 Stabuc-Silih M, Ravnik-Glavac M, Glavac D, Hawlina M, Strazisar M. 2009. Polymorphisms in 591 COL4A3 and COL4A4 genes associated with keratoconus. Molecular Vision 15:2848592 2860.

593

594

595

596

597

598

599

600

601

602

603

604

605

606

607

608

609

610 normal in keratoconus corneas but increases with scarring. Cornea 18:599-605.

Tang YG, Rabinowitz YS, Taylor KD, Li X, Hu M, Picornell Y, Yang H. 2005. Genomewide linkage scan in a multigeneration Caucasian pedigree identifies a novel locus for keratoconus on chromosome 5q14.3-q21.1. Genetics in Medicine 7:397-405. DOI: 10.109701.GIM.0000170772.41860.54.

Tuft SJ, Hassan H, George S, Frazer DG, Willoughby CE, Liskova P. 2012. Keratoconus in 18 pairs of twins. Acta Ophthalmologica 90:e482-486. DOI: $10.1111 / \mathrm{j} .1755-$ 3768.2012.02448.x.

Tyynismaa H, Sistonen P, Tuupanen S, Tervo T, Dammert A, Latvala T, Alitalo T. 2002. A locus for autosomal dominant keratoconus: linkage to 16q22.3-q23.1 in Finnish families. Investigative Ophthalmology \& Visual Science 43:3160-3164.

Udar N, Atilano SR, Brown DJ, Holguin B, Small K, Nesburn AB, Kenney MC. 2006. SOD1: a candidate gene for keratoconus. Investigative Ophthalmology \& Visual Science 47:33453351. DOI: 10.1167/iovs.05-1500.

Valgaeren H, Koppen C, Van Camp G. 2018. A new perspective on the genetics of keratoconus: why have we not been more successful? Ophthalmic Genetics 39:158-174. DOI: 10.1080/13816810.2017.1393831. 
611 Vincent AL, Jordan CA, Cadzow MJ, Merriman TR, McGhee CN. 2014. Mutations in the zinc 612 finger protein gene, ZNF469, contribute to the pathogenesis of keratoconus. Investigative 613 Ophthalmology \& Visual Science 55:5629-5635. DOI: 10.1167/iovs.14-14532.

614 Vitart V, Bencić G, Hayward C, Skunca Herman J, Huffman J, Campbell S, Bućan K, Navarro P, 615 Gunjaca G, Marin J, Zgaga L, Kolcić I, Polasek O, Kirin M, Hastie ND, Wilson JF, Rudan 616 I, Campbell H, Vatavuk Z, Fleck B, Wright A. 2010. New loci associated with central 617 cornea thickness include COL5A1, AKAP13 and AVGR8. Human Molecular Genetics 618 19:4304-4311. DOI: $10.1093 / \mathrm{hmg} / \mathrm{ddq} 349$.

619 Xu X, Zhang X, Cui Y, Yang H, Ping X, Wu J, Yu X, Jin X, Huang X, Shentu X. 2020. Three 620 novel variants identified within ECM-related genes in Chinese Han keratoconus patients. Scientific Reports 10:5844. DOI: 10.1038/s41598-020-62572-0.

Yan X, Liu Z, Chen Y. 2009. Regulation of TGF-beta signaling by Smad7. Acta Biochimica Et Biophysica Sinica 41:263-272.

624 You J, Corley SM, Wen L, Hodge C, Höllhumer R, Madigan MC, Wilkins MR, Sutton G. 2018. 625 RNA-Seq analysis and comparison of corneal epithelium in keratoconus and myopia patients. Scientific Reports 8:389. DOI: 10.1038/s41598-017-18480-x.

Yu F-X, Guan K-L. 2013. The Hippo pathway: regulators and regulations. Genes \& Development 27:355-371. DOI: 10.1101/gad.210773.112. $10.1038 /$ cr.2008.328. keratoconus and normal cornea. Chinese Medical Journal 115:1401-1404. 


\section{Figure legends}

636 Figure 1. Hierarchical clustering analysis of gene expression

637 A heat map indicates hierarchical clustering (Ward linkage) of keratoconus (KTCN) and non638 KTCN samples (KR) based on the expression values of 36 analyzed genes. Data was clustered as 639 groups of genes (vertical line) and groups of individuals (horizontal line). Color scale encodes Z640 score of gene expression; results indicated in green and red point to expression values above and 641 below the median, respectively. Upper color labeling shows KTCN samples in red, and non-KTCN 642 samples in blue.

643 Figure 2. Gene expression correlations between RT-qPCR and RNA-Seq data

644 Diagram shows relationship between binary logarithms $(\log 2)$ of the fold change values obtained 645 from RT-qPCR (vertical axis) and RNA-Seq (horizontal axis) experiments for 36 analyzed genes.

646 The Pearson correlation and linear model coefficients, as well as linear regression line are 647 indicated. 


\section{Figure 1}

Hierarchical clustering analysis of gene expression

A heat map indicates hierarchical clustering (Ward linkage) of keratoconus (KTCN) and nonKTCN samples (KR) based on the expression values of 36 analyzed genes. Data was clustered as groups of genes (vertical line) and groups of individuals (horizontal line). Color scale encodes Z-score of gene expression; results indicated in green and red point to expression values above and below the median, respectively. Upper color labeling shows KTCN samples in red, and non-KTCN samples in blue. 

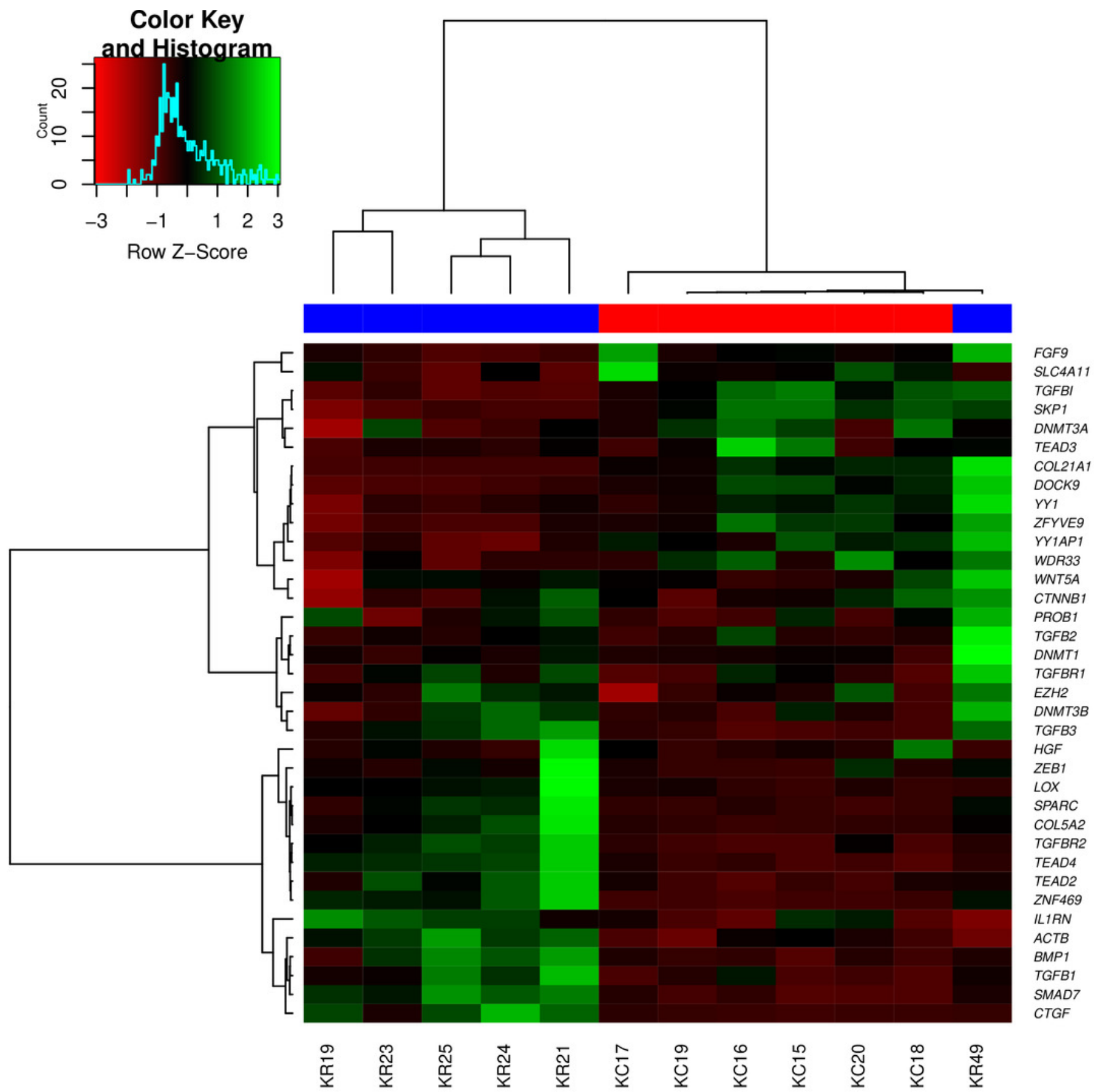
Figure 2

Gene expression correlations between RT-qPCR and RNA-Seq data

Diagram shows relationship between binary logarithms $(\log 2)$ of the fold change values obtained from RT-qPCR (vertical axis) and RNA-Seq (horizontal axis) experiments for 36 analyzed genes. The Pearson correlation and linear model coefficients, as well as linear regression line are indicated. 


\section{Real-time PCR vs RNA-Seq}

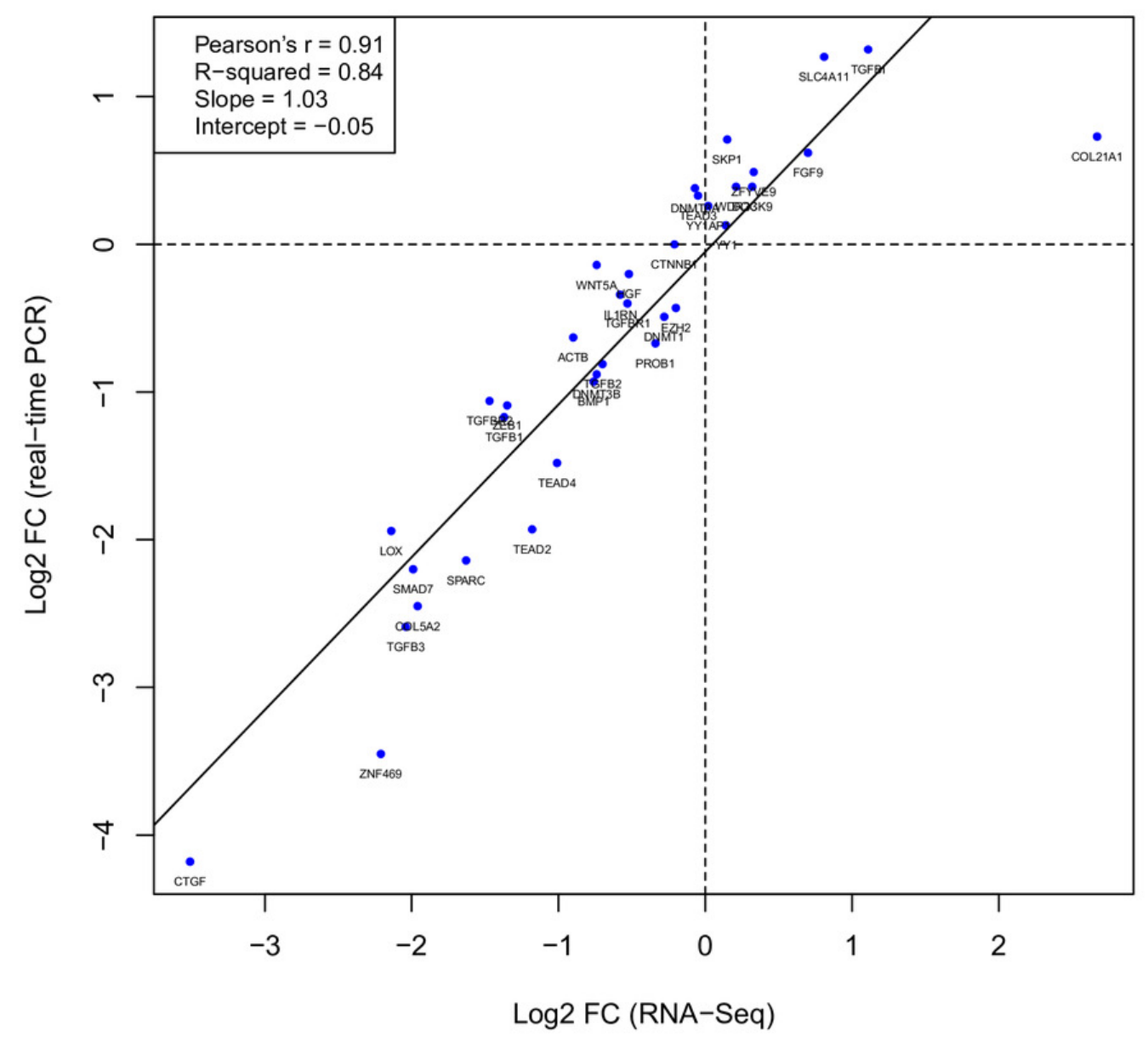




\section{Table $\mathbf{1}$ (on next page)}

Changes in the gene expression level determined using RT-qPCR in the KTCN corneas compared with the non-KTCN corneas 
1 Table 1. Changes in the gene expression level determined using RT-qPCR in the KTCN corneas 2 compared with the non-KTCN corneas

3

\begin{tabular}{|c|c|c|c|}
\hline Gene & Pvalue_adjusted & FC & $\log 2 \mathrm{FC}$ \\
\hline \multicolumn{4}{|c|}{$\begin{array}{l}\text { A. Genes selected based on RNA-seq study from top molecular pathways overrepresented } \\
\text { across deregulated genes, encoding core elements of collagen synthesis and maturation } \\
\text { pathways, the TGF- } \beta \text {, Hippo, and Wnt signaling pathways, as well as their potential } \\
\text { regulators }\end{array}$} \\
\hline ACTB & 0.133475711 & 0.644242264 & -0.6343248 \\
\hline$B M P 1$ & 0.113652146 & 0.525332459 & -0.9286974 \\
\hline COL21A1 & 0.590726465 & 1.655146746 & 0.7269591 \\
\hline COL5A2 & 0.128826872 & 0.183439285 & -2.4466255 \\
\hline$C T G F$ & 0.113652146 & 0.055297401 & -4.1766445 \\
\hline DNMT1 & 0.360409941 & 0.710043749 & -0.4940202 \\
\hline DNMT3A & 0.214127903 & 1.303679974 & 0.3825898 \\
\hline$D N M T 3 B$ & 0.219396173 & 0.543577449 & -0.8794425 \\
\hline$E Z H 2$ & 0.184023747 & 0.741651443 & -0.4311868 \\
\hline LOX & 0.2178701 & 0.261069481 & -1.9374943 \\
\hline SMAD7 & 0.076671938 & 0.217447449 & -2.2012613 \\
\hline TEAD2 & 0.113652146 & 0.262175317 & -1.9313962 \\
\hline TEAD3 & 0.321839445 & 1.255782411 & 0.3285865 \\
\hline TEAD4 & 0.1055257 & 0.357861338 & -1.4825274 \\
\hline$T G F B 1$ & 0.113652146 & 0.443800498 & -1.1720168 \\
\hline$T G F B 2$ & 0.405724701 & 0.571357569 & -0.8075342 \\
\hline TGFB3 & 0.076671938 & 0.165798806 & -2.5924945 \\
\hline TGFBRI & 0.199938575 & 0.760414605 & -0.3951419 \\
\hline$T G F B R 2$ & 0.113652146 & 0.480308326 & -1.0579673 \\
\hline WNT5A & 0.710742768 & 0.904652905 & -0.1445637 \\
\hline YY1 & 0.751277265 & 1.092918686 & 0.1281861 \\
\hline YY1AP1 & 0.367206418 & 1.193550658 & 0.2552598 \\
\hline ZFYVE9 & 0.314142017 & 1.400497193 & 0.4859391 \\
\hline
\end{tabular}

$B$. Genes previously reported as involved in KTCN based on their function, detection of putative variants within the gene, localization within the linkage region, or localized in proximity to variants associated with KTCN

\begin{tabular}{llll} 
CTNNB1 & 0.994110913 & 1.000820444 & 0.0011832 \\
DOCK9 & 0.425606848 & 1.313649696 & 0.3935806 \\
FGF9 & 0.556166983 & 1.531641011 & 0.6150782 \\
HGF & 0.826503411 & 0.870795372 & -0.1995944 \\
ILIRN & 0.271724961 & 0.791829931 & -0.3367375 \\
PROB1 & 0.271724961 & 0.628154772 & -0.6708080 \\
SKP1 & 0.077097944 & 1.632464428 & 0.7070516 \\
SLC4A11 & 0.133475711 & 2.408981021 & 1.2684230 \\
SPARC & 0.128826872 & 0.226367696 & -2.1432600 \\
TGFBI & 0.113652146 & 2.488055868 & 1.3150189 \\
WDR33 & 0.292948374 & 1.306800874 & 0.3860393 \\
\hline
\end{tabular}




\begin{tabular}{llll}
\hline ZEB1 & 0.321839445 & 0.469715758 & -1.0901401 \\
ZNF469 & 0.076671938 & 0.091553859 & -3.4492355 \\
\hline
\end{tabular}

4 